\title{
Disability Arts and Visually Impaired Musicians in the Community
}

\author{
David Baker and Lucy Green \\ Oxford Handbook of Community Music, 2018 \\ edited by Brydie-Leigh Bartleet and Lee Higgins
}

\begin{abstract}
Keywords
This chapter reports on a multifaceted 'disability arts scene' in music worldwide that comprises visually impaired (i.e., blind and partially sighted) instrumentalists, singers, composers, producers, and others across a range of musical styles and genres. Some such musicians work alone but are usually deeply involved in networks. Others join community music ensembles that can be made up of musicians with a range of disabilities including visual impairments, or that consist entirely of visually impaired people. When promoting their community music participation, some visually impaired musicians draw on the history and traditions of the blind in music across the world, and thus exists the lore concerning special dispensations in the absence of sight. Yet there are also visually impaired musicians who distance themselves from that self-identity. The chapter explores how members of this unique socio-musical group consider the aforesaid 'scene' and its integral community music, and how their interpretations correspond or clash; it introduces key matters of accessibility, independent mobility, identity, musical approach and media, notions of discrimination, and social inclusion.
\end{abstract}

Keywords: music and disability, visual impairment, blindness and partial sight, social inclusion and music, accessibility and music, musical identities

\section{Introduction}

This chapter explores visually impaired musicians' self-identities in relation to community music participation and the notion of a 'disability arts scene' in the United Kingdom. ${ }^{-1}$ Throughout history and worldwide, a range of traditions have been associated with visually impaired musicians. Some examples include individuals and groups in the early blues, jazz, and gospel of the US South (e.g., Batterson, 1998; Fuqua, 2011; Harrah, 2004; Rowden, 2009; Southall, 1999); musicians of the Limba ethnic group in Sierra Leone (Ottenberg, 1996); a tradition of blind minstrelsy in the Ukraine (Kononenko, 1998); and the Biwa Hōshi (lute) priests and guilds of blind musicians in Japan reaching back to feudal times (De Ferranti, 2009; Groemer, 2012; Lubet, 2011). There are, and have been, many prominent individual visually impaired musicians in current and recent times too, such as the country singer Hayley Oliver, jazz musicians Art Tatum and George Shearing; global popular figures such as Ray Charles and Stevie Wonder; and internationally recognized classical musicians, such as the concert pianist Nobuyki Tsujii, the singer Andrea Bocelli, the lute and theorbo player Matthew Wadsworth, and the composer Michael Stimpson, to name but a few. Lore has also emerged from the history and traditions of visually impaired musicians, often casting them as having special dispensations, such as religious wisdom (Groemer, 2012; Kononenko, 1998), or intrinsic musicality; and the question of whether or not this social group has heightened musical capacities has been explored by social, psychological, and educational research too (see, e.g., Dimatati et al., 2012; Hamilton, Pascual-Leone \& Schlaug, 2004; Ockelford, 2007; Ockelford et al., 2006; Ockelford \& Matawa, 2009; Welch, 1988).

Contemporary examples of community music groups and performing ensembles that are specifically geared towards visually impaired people around the world include the Al Nour Wal Amal ('Light and Hope') Chamber Orchestra in Egypt, which is comprised of visually impaired women (see Lababidi \& El-Arabi, 2002; Lubet, 2011); the Korean Traditional Music Orchestra of the Blind; the Argentinian National Symphony Blind Band 'Maestro Pascual Grisolia'; and, in Chennai, India, the St. Louis 
Blind Orchestra, which performs music from Tamil cinema. ${ }^{2}$ Groups in the UK are, for example, the My Sight Choir in Nottingham, which is connected with a local visual-impairment charity (formerly Nottingham Royal Society for the Blind); the Salisbury Blind Choir, Wiltshire; and the St Vincent's School Ukulele Band, Liverpool, which was created for purposes of 'reverse inclusion', that is, getting sighted community members into the school to interact with its visually impaired children..$^{-3}$ Many groups also exist that are geared to members with a range of disabilities, including visual impairment — for example, London Symphony Orchestra's 'Create' for adults with disabilities to be active music makers and performers (funded by the City Bridge Trust). ${ }^{4}$

In this chapter we focus mainly on two UK organizations. One is the Baluji Music Foundation, which offers participatory community workshops for disabled musicians at any level of musical ability, and also runs a performing group called the Inner Vision Orchestra, comprised entirely of visually impaired members. The other is the British Paraorchestra, a multi-disability group, including several visually impaired musicians, which provides professional performances, drawing its members from amongst professional, semi-professional, and amateur musicians. We discuss the aims of these organizations and the perceptions of some of their members. We also thread in personal stories - for example, individuals who are uncomfortable or uncertain about the notion of a disabled musical identity or, indeed, community music at all, particularly when it is perceived to promote itself as 'active resistance to institutionalized structures' (Higgins, 2006, p. 7). We consider how and why activism against musical approaches that are seen to exclude, or projects that aim to counter marginality and discrimination, are regarded with suspicion and even disliked by some. We look at various musicians' perceptions of underemployment and employment discrimination, and how such perceptions can impel these musicians towards community music contexts as well. We aim to present a multidimensional portrait of perspectives amongst these visually impaired musicians as they relate to community music, showing that this type of participation is far from straightforward.

Ludlow (1995) argued that, whilst there is naturally support for an organization to forefront the interests of its members, visually impaired musicians generally are disinterested in the idea of a 'blind music culture'; therefore, the concept of a 'disability arts scene' or 'disabled music' has very little meaning for most of them. In fact, we found strong views on both sides of the coin, as well as many mixed opinions amongst our respondents. It is implausible to deny the existence of a 'disability arts scene' because there do exist ensembles such as those previously mentioned, where musicians come together either in professional or community music contexts. Moreover, they do so as a result of, for instance, shared life experiences, a need for belonging to a disabled community, to find accessible ways to make music, a desire to challenge the problems of independent mobility that affect their musical participation, or many more factors. We found that some individual musicians and ensembles, amateurs and professionals, were keying into the previously mentioned backdrop of the lore surrounding notions of heightened musical gifts amongst blind musicians in their self-promotion, or marketing approaches (whether for amateur or professional purposes); whereas others were keen to distance themselves from any such scene. Some even found it an abhorrent notion detracting from equality with sighted musicians, as we will explain.

\section{What do we mean by 'musician', 'visually impaired', and 'disability'?}

Our project (see note 1) considered a 'musician' as anyone involved in music-making, whether as a singer or instrumentalist, conductor, DJ, composer, or other music maker, and anyone who selfidentifies as being involved in teaching music in any capacity. They could participate in any musical genre, style, context, or role, from adult beginners, to amateurs, semi-professionals and top professionals. In this chapter, though, our specific foci are the 'insider' perceptions of community music participants, and also the standpoint of those within this wider group of sensory-impaired people on community music, some of whom label themselves as semi-professional or professional musicians, and who choose not to participate in any disability-related capacity. 
The project investigated adult musicians 18 years of age or over, whose visual acuity and/or visual fields met the requirements for official registration as visually impaired in the United Kingdom, even if they were from elsewhere in the world. ${ }^{-}$It must already be clear from the discussion so far, that terminology is used variously in this arena. Usage differs from person to person, organization to organization, and worldwide, including terms such as 'blind', 'partially sighted', 'severely sightimpaired', 'sight-impaired', or having 'vision loss' and 'low vision'. For the purposes of this chapter, we use the umbrella term 'visually impaired', as adopted by ophthalmologists in the United Kingdom to denote respondents along a continuum from 'sight-impaired', that is people with some light perception (perhaps functional to some extent); to 'severely sight-impaired', a higher degree of impairment (that is having negligible or no functional vision as it relates to daily life, perhaps only residual light perception); or, indeed, complete blindness (i.e., no light perception). It may be technically misleading at times to align 'partially sighted' with 'sight-impaired', and 'severely sightimpaired' with 'blind'. People in the 'severely sight-impaired' category may, in fact, have light perception and, as such, are not 'blind', although, to the layperson, they appear to be. However, for the purposes of clarity for people new to this arena, we will, at times, use two main terms, 'blind' and 'partially sighted', underneath the umbrella term of 'visually impaired'. Other terms naturally appear in quotes from our participants or other sources.

The terms 'impairment' and 'dis-ability', which are used in casual dialogue and across different academic texts, can be read as what a person is unable to do. As such, they tend to imply a 'deficit model'. As one of our respondents put it: 'Far too often, visually impaired people are told what they cannot do rather than what they can do' (quote, anon.). Another contact by email said she preferred to be understood as 'sightless' and not 'impaired'. In contemporary Western culture, to be disabled is to be disadvantaged, regardless of how much success one achieves individually. That is because costs are extracted if one is seen as a member of a poorly regarded group. Being identified as a 'weak' class invites oppression (Silvers, Wasserman, \& Mahowald, 1998, p. 54). We employ the term 'visually impaired', despite these disadvantages, because it is the most widely used and most readily identifiable term.

\section{Project methodology and methods}

Throughout 2013 and 2014, the project received generous support with advertising on webpages and Facebook pages, and through e-newsletters sent to clients (e.g., help from the Blind and Low Vision Education Network [BLENNZ], New Zealand; the European Blind Union; the Music Education Network for the Visually Impaired [MENVI], US; Music Mark, the UK Association for Music Education; the National Federation of the Blind, US; the Royal London Society for Blind People [RNIB], UK; Thomas Pocklington Trust, UK; Vision Australia; the World Blind Union; and many more). Initially, the RNIB facilitated contact with some of their clients too, and thereafter, "word of mouth' took over. These organizations directed people to the website we created for the venture. Some respondents also put us in touch with colleagues or friends, sometimes asking them to contact us; and quite quickly we were independently emailed by people who had come across us by one means or another. We soon found ourselves at the heart of national and global networks of musicians. ${ }^{6}$

Data came from detailed life history interviews ${ }^{\underline{T}}$ (lasting between an hour and two and a half hours, audio recorded and transcribed verbatim) and an online Survey Monkey questionnaire, which could also be completed with us by telephone or Skype (most respondents preferred the latter), to source both qualitative answers to questions and quantitative responses to closed, multiple response and rating-scale items. NVivo10 and SPSS software aided our analysis. Altogether we collected data from 225 people ${ }^{8}$ as follows: fifty-four life history interviews; questionnaire data from twenty of the visually impaired interview sample. We also collected questionnaire data from an additional 171 visually impaired respondents (so 191 questionnaire responses overall). Amongst the interview 
participants, the spread was biased towards people living in the United Kingdom, with forty-two respondents, but also six from the United States, two from Australia, and individuals from Colombia, Indonesia, Malaysia, and New Zealand. The reasons for this were partly pragmatic, and partly to do with the fact that the project was UK-funded. The mean age of the fifty-one interviewees who declared it was 44.04 years (standard deviation, $\mathrm{SD}=15.28$ ). Thirty-five of the interviewees classed themselves as 'severely sight-impaired' (blind), and thirteen as 'sight-impaired' (partially sighted).

The interviewees played a range of instruments, often in combinations, with twenty-eight keyboard players, twenty-two singers, ten percussionists, and varying numbers of others playing woodwind, string, and brass instruments. There were seventeen composers, with seven who were 'notation-based' (i.e., utilizing Braille, large-print, or modified stave notation), twelve who produced or recorded electronic music, and a DJ working with Bhangra music. ${ }^{9}$

The questionnaire responses also came from a wide range of countries, with a bias towards larger English-speaking countries. There were seventy-eight ( 40.84 per cent) from the UK; forty-eight (25.13 per cent) from the United States; twenty-three (12.04 per cent) from Australia; thirteen (6.81 per cent) from Colombia; five ( 2.62 per cent) from New Zealand; four (2.09 per cent) from Canada; two (1.05 per cent) from Austria, two from Italy, and two from Kenya; and single respondents from Chile, Croatia, Egypt, Estonia, Fiji, Ghana, India, Indonesia, Italy, Japan, Malaysia, the Philippines, the Republic of Ireland, and Russia. One hundred and forty-six (79.44 per cent) classed themselves as 'severely sight-impaired', and the rest 'sight-impaired'.

There was a good distribution of ages within the questionnaire sample, with forty of 18-24 years; fifty of 25-34 years; twenty-nine of 35-44 years; twenty-seven of 45-54 years; thirty-three of 55-64 years; and twelve of 65-74 years. These musicians played a range of instruments associated with various genres, including classical, folk, gospel, hip hop, Latin, popular, traditional, and other 'world' music. Their instruments included banjo, ukulele, mandolin, Indian harp, Indian sitar, Iranian tar (a plucked string instrument), viola da gamba, violin, cello, penny whistle, recorder, Western concert flute, Japanese shakuhachi flute, clarinet, saxophone, didgeridoo, trombone, guitar (acoustic and electric), harmonica, harmonium, accordion, keyboards (electronic, harpsichord, 'church' organ, and piano), Western (orchestral and kit) percussion, Indian dhol, and African percussion. Overall (i.e., the interview and questionnaire sample), the youngest respondent was 18 years of age, and the oldest was 73. All our respondents spoke English, either as a first language or an alternative language.

An information sheet was given to the interviewees in Microsoft Word format (to be accessed by visually impaired people using assistive technologies; see note 6). There was also the offer of a copy in Braille or another preferred format, which none required. The document detailed our aims, procedures, and ethical arrangements. ${ }^{10}$ It was made clear that participation was voluntary, that we would provide further information if desired, and that participants could withdraw at any point; none withdrew. We agreed with the respondents that arranging an interview comprised 'informed consent' (Cohen, Manion, \& Morrison, 2000; Glesne \& Peshkin, 1992; Gregory, 2003; Silverman, 2000; Ryen, 2004). For the sake of fidelity, the transcribed life texts were returned to interviewees for evaluation (Atkinson, 1998, 2001). We asked respondents to flag comments not to be reported, which they seldom did. Furthermore, we offered to use pseudonyms and to remove other 'identifiers' from transcripts and our reports, yet many said they were happy to be named.

\section{Findings}

\section{The Baluji Music Foundation}

Baluji Shrivastav (sitar, dilruba, surbahar, pakhavaj, tabla), who is blind, is a London-based Indian musician, composer, and advocate for the rights of visually impaired musicians, as well as others with disabilities. He has performed and recorded with notable popular musicians including Stevie Wonder, Massive Attack, Annie Lennox, and Madness, in addition to jazz musicians like Andy Sheppard and 
Guy Barker. He founded the Baluji Music Foundation in 2012, a registered UK charity dedicated to encouraging the participation of, to use the Foundation's term, 'differently-abled' people in music. ${ }^{11}$ It presents music workshops for all ages and abilities in Indian folk and classical music, Hindu religious songs, sung Urdu poems (ghazals), and contemporary fusion music.

The Inner Vision Orchestra, a world music ensemble of visually impaired musicians, is integral to the Foundation's venture. The orchestra aims both to give opportunities to visually impaired musicians, and to raise awareness, with stories and dialogue on the issues surrounding visual impairment threaded into its concerts. Its website says the orchestra's aim is as follows:

To prompt blind and visually-impaired musicians to address the imbalance of their absence ... It also aims to give confidence to blind and visually-impaired musicians through the experience of workshops and performances. ${ }^{12}$

The Inner Vision ensemble is a "campaigning tool to encourage recognition of the particular problems facing blind or visually impaired performers' (Clerk, 2014, p. 18). Inner Vision aims to address the problems visually impaired musicians face with transport arrangements to rehearsals and concerts, and their limited opportunities for socializing and networking. Baluji's wife Linda Shanson, who is sighted, supports Baluji in marketing the Baluji Music Foundation, including organizing tours for Inner Vision. The orchestra has attracted rave reviews from national and international media, plus national funding. It currently contains fourteen members from a wide range of musical backgrounds and cultures. Its 2013 UK tour featured: Abi Baker (pianist and violinist), Rikki Jodelko (guitarist), Fereshteh Khosroujerdy (singer), Takashi Kikuchi (violinist), Tristram Llewellyn (keyboardist), Victoria Oruwari (singer), Peggy Scott (finger cymbalist), Baldev Singh (tabla player), and Ziad Sinno (oud player). Drawing upon the cultural heritage and musical interests of its members, the group combines different world-music genres. Its repertoire includes set compositions and improvised pieces, moving between songs from Iran, Lebanon, Afghanistan, India, Nigeria, to gospel and blues, Indian ragas, and Western classical composition. There are musicians of diverse musical backgrounds and levels of musical experience; the ensemble, which recognizes the transformative power of music in people's lives, treads a fine line between a community music ensemble wherein anyone is welcome, and a professional outfit undertaking well-publicized national tours.

Baluji conveyed a story to us reinforcing his belief that confidence is the essence of musical success for the visually impaired. He explained that when he was in Paris some years ago, the people with whom he was staying locked him in their house for twenty-five days: they were concerned that a blind person would mistakenly leave doors or windows open, thus inviting the possibility of intruders. One day, Baluji went to leave. 'Where are you going?' his hosts protested. He replied 'I don't like it here; I can't stand all this confinement'. He wandered around the city repeatedly calling out in English: 'Where is the railway station? Where is the railway station?' Eventually, a student who understood his plea took him there. With no French, the ticket office might have been difficult, so Baluji boarded a train without purchasing a ticket. On the train, the ticket inspector, realizing he was blind, helped, sold him a ticket, and kindly gave advice on his journey. 'Once blind people do take steps forward, everything works out for them; this need for positive role models and developing confidence is why I started the Inner Vision Orchestra', Baluji said to us. Afterwards, he smiled and remarked on his friend Ziad Sinno, an oud player in the orchestra. Baluji remarked 'When I started the Inner Vision Orchestra, my friend Ziad said "How will I get my instrument to the concert venue?" and I replied "You put one foot forward and the other will follow", This anecdote is about independent mobility in the visually impaired, as well as confidence. Baluji and Linda underscored that Inner Vision was a 'process' and an important politically driven endeavour: that is, once the blind musicians within their ensemble developed confidence, and wider awareness was raised of their high abilities, they would be able to achieve musical participation alongside their sighted equals. When that happened, Inner Vision would become obsolete, they said, and that was their 'ultimate goal'. 


\section{The Paraorchestra}

The British Paraorchestra was founded in January 2012 by the renowned conductor, Charles Hazlewood, to coincide with the London Paralympics. ${ }^{13}$ It comprises members with various disabilities, some of which are not sight-related. Of those with visual impairments, some were our research participants. The Paraorchestra currently lists twenty-six members on its website, and also encompasses instruments such as the trumpet, trombone, clarinet, and guitar. Like Inner Vision, its members range from amateurs to semi-professional and professional musicians, some of whom have found barriers in finding performing opportunities. Hazlewood had noted a lack of disabled musicians in the orchestral field, and this endeavour is, indisputably, politically charged and quite synchronous with that of Inner Vision:

Charles Hazlewood has been a relentless advocate for broadening access to orchestral music worldwide, and in all the years he has toured the world working with orchestras, he realized almost none had a single disabled musician. ${ }^{14}$

[Those Hazelwood] ... had to win round were the Prime Minister and the then Culture Secretary, Jeremy Hunt. 'The world of disability arts is a small one', he reflects when we meet on London's South Bank after a rehearsal of the British Paraorchestra. 'And so it can take a while for the trust that some of the long-established groups in this particular world have established to extend outwards to other areas - such as orchestras. People worry that they might be a gimmick or being set up for the wrong reasons'. ${ }^{15}$

The highlight of the British Paraorchestra's first year was undoubtedly the Closing Ceremony of the Paralympic Games, when they inspired a global audience of millions with their thrilling performance with Coldplay. Channel 4's 'Great British Paraorchestra' documentary, screened just before the Paralympics Closing Ceremony, followed the remarkable story of some of the musicians as they prepared for their official debut with the British Paraorchestra at Orchestra in a Field, in the grounds of Glastonbury Abbey in July 2012. This was followed by headline performances at the Unlimited Festival, Southbank Centre, as part of the London 2012 Festival, and at the prestigious Snape Proms in Aldeburgh. ${ }^{16}$

The Paraorchestra aims to 'increase the profile and visibility of disabled musicians on the world stage', to 'challenge perceptions of disability and remove barriers to music-making for disabled musicians', and to 'encourage greater investment in the development of pioneering assistive technology for disabled musicians' (website, as previous). The venture used the London 2012 games as its primary vehicle, and its connection with the super-group Coldplay had seventeen of its members joining this world-famous pop band at the closing ceremony. It has continued to put on performances thereafter.

\section{Community music for the visually impaired: its rationale and the relevance of perceived marginalization and underrepresentation in the music industry}

Lee Higgins considers community music as communal music-making and an active intervention between a music leader or leaders and participants, which might draw in other areas of interest such as lifelong learning, cultural diversity in music, and social justice. ${ }^{17}$ This resonates with the aims and practices of the Baluji Music Foundation discussed earlier. Engendering confidence in the mobility needed for integrated musical participation with the sighted was a leitmotif amongst members of the group, both those involved in the workshops and in the Inner Vision Orchestra to whom we spoke. For some, there was isolation in their lives, which was reduced when they united. Such participants remarked on a lack of acceptance in the wider musical society, despite the notoriety of famous blind musicians, or, indeed, amazement by sighted audiences at their personal skills and what could be achieved. 
Mainly acceptance is the most important thing [for the visually-impaired musician], I guess .... If only I could find a group that accepted me as a visually-impaired person. I hate to sound a negative person but that's the way I feel .... The main opportunities that I've had are Inner Vision; the main barrier has been being accepted as a musician. (Ziad Sinno, oud player, blind; interview, UK)

Prejudice can occur, too, due to lack of understanding and awareness about visually impaired musicians' skills amongst the sighted; or simple ignorance and perhaps fear of their practical needs (e.g., issues of transport, navigating concert stages, use of accessible music technologies, etc.). Some of our participants placed themselves on an equal footing musically by sidestepping any musical reasons for problems related to performing or rehearsing music. Yet for others there were no doubt insurmountable musical and practical reasons for problems related to, for example, access to materials and repertoire (including large print, modified stave notation or Braille scores), ${ }^{18}$ mobility, and so on. Undoubtedly, the credibility and relative balance of these matters was felt variously by our interviewees; it was also related to the musical context in which they participated, with, in some cases, participation that rested less on sight reading and more on memorization or oral (sic) traditions ${ }^{19}$ being less problematic. During our conversations, we kept in mind the danger of suggesting that our respondents' perceptions would automatically match the realities of their situation (e.g., in terms of inadequacies in fiscal support for mobility, discrimination, or isolation), but, of course, they might well. Employment discrimination, for instance, can easily be felt most strongly, but equally, it is hard and costly to prove legally. However, these types of perceptions did tell us much about their selfidentities, the emergence of 'the scene' and why some respondents came together as community musicians for their mutual benefit.

Our questionnaire probed a number of issues of employment across the countries we explored. To the question, 'How would you describe your highest level of musical activity currently?', 24.61 per cent of the respondents $(\mathrm{n}=47)$ answered 'amateur, beginner, to advanced (e.g., Grade 8) standard'; 9.95 per cent (nineteen) 'amateur, competent (e.g., diploma standard)'; 9.95 per cent (nineteen) 'amateur of professional standard'; 16.75 per cent (thirty-two) 'semi-professional'; 26.18 per cent (fifty) 'professional'; and there were twenty-four who marked 'no response'. We also asked those who classed themselves as professional musicians, 'How much of your income do you currently make from music?' Only 24.08 per cent (forty-six) stated they made over 50 per cent of their income from music. We questioned this professional-standard group about Access to Work ${ }^{20}$ grants in the United Kingdom, too, as nineteen respondents had one (24.36 per cent of seventy-eight UK citizens); and, of twenty UK citizens making ' 50 per cent or more' of their income from music, 35 per cent (seven) had an Access to Work grant. This suggests that national fiscal support mechanisms to assist the disabled with work are important in allowing visually impaired people to access music careers. However, the low quantity of those who were actually making a large portion of their income from music but who considered themselves professionals is suggestive of underrepresentation in the industry. Here we need to be a little circumspect, as many sighted musicians would specify themselves as professional standard musicians without having full-time professional careers. However, perceived underemployment has an unsettling interaction in the lives of these musicians it seems, in that some respondents thought it compelled them into amateur community music contexts, despite having professional standards of performance, where they challenged ignorance within wider society and came together as a supportive mutually interested group.

\section{Promotion through disability and contrasting perspectives}

Some professional visually impaired musicians use their impairment as part of their marketing strategy, tapping into that lore we mentioned earlier about blind people having special gifts. Kevin Kern, who is partially sighted, is an official Steinway Artist and composer-pianist from the United States with international tours, alongside producing successful recordings and writing music used for 
television commercials. His music sits in the New Age genre. Either by Kevin's own choice or that of others, his visual impairment is highlighted in his marketing. Kevin has been described as having 'phenomenal musical abilities', ${ }^{21}$ as the 'Stevie Wonder of classical music' who 'plays the music of light' and 'paints sound paintings', and as one who 'sees the music other musicians can only hear'. ${ }^{22}$ So, it would be impossible for Kevin to distance himself from visual impairment, even if he wanted to. As another example, James Risdon is a professional recorder player who told us he had often received complements from sighted musicians for his aural abilities, related to his blindness. Joe Buck, also partially sighted, is another such artist from the United States. Joe composes music for film. He overdubs himself playing a variety of instruments. He forwarded a link to us of a YouTube clip of his track 'Kitchen Caliente' with text that read as follows:

A visually-impaired musician teaches himself to play six real instruments in order to become his own blues, funk, rock, soul and country band! His name: Jammin' Joe Buck. JJB sells his music all over the world via online retail stores with radio play in four countries along with songs in film. Please share this video and help spread the word about this visually-impaired music artist! $!^{23}$

Joey Stuckey, who is blind, is a rock musician and music producer from the US who owns a recording studio. He recently released a single entitled 'Blind Man Driving', which he dedicated as the theme tune of our two-day international project conference, 10-11 March 2015, which we held at the UCL Institute, London. Joey also sent us a humorous video of himself attempting to drive a golf truck, which he described as showing 'a can-do attitude and a sense of fun!'

In a more overtly political spirit, Kenyan pop musician and rapper, Paul 'Mpofu Namba 1' Mugambi sent us a YouTube link to his song 'Never, Never Ever Give Up!' with surrounding text describing himself as a 'blind disabled rights activist'. ${ }^{24}$ Paul's promotional material reads 'will stop at nothing to ensure representation of the disabled in terms of their access to employment, services and other amenities' and he has appeared on television (with a short biography, 6 March 2014). His stage name is 'Mpofu Number 1', which translates as 'Blind Number 1'. Paul's music started as a student at Kenyatta University, Nairobi, in 2002, where he danced and sang his compositions in front of crowds during the university's culture week. His songs, which are in Swahili and English, are about social issues, including abortion, discrimination, and other matters. Paul's music video for 'Never Give Up!' features him using a white cane, reading Braille, and performing to children at a school. ${ }^{25}$ This track, and 'My Ability', which is a counterpoint to the notion of disability, has been marketed with 50 per cent of the profits going to Oxfam. ${ }^{26}$

Similar approaches also mark many community music organizations for visually impaired people and/or those with a range of disabilities. Even by the names 'My Sight Choir' or 'Inner Vision', for example, there is the explicit message that the choir or ensemble is formed partly around issues of visual impairment, not just of making music or performing together.

Within amateur and community contexts as much as professional musical activity, visually impaired musicians cannot easily sidestep the lore and traditions of 'blind musicianship', particularly when their sensory impairment is obvious to audiences (e.g., when they wear dark glasses, carry a white cane, or have a guide dog); and sometimes they choose to utilize this backcloth (e.g., to whet the appetite of audiences or for disability campaigning, as is the case with Paul Mugambi). So, how community music ensembles such as these are understood, with their integral disability campaigning, is not a straightforward matter of 'insiders' who participate in community music and 'outsiders' with professional careers within the wider visually impaired society who disapprove of its aims as counterproductive to social inclusion. However, there is some of that, as we explain next.

Moreover, many within the visually impaired socio-musical group may feel that keying into a 'blind identity' is simply unavoidable rather than about free will, which is significant, given the existence of 
the aforesaid community music ensembles and how they are promoted to sighted audiences - for example, through wonderment at visual impairment and musical ability. Our questionnaire asked whether or not participants perceived any prestige attached to being a visually impaired musician. Of the 138 responses, only 38 agreed (19.90 per cent of the total of 191 questionnaire responses).

\section{Dissenting voices on 'disability arts' and community ensembles}

Through the activities and rationales of community ensembles such as those discussed, and the promotional strategies of some individual musicians or, in the case of professionals, their agents, we see a number of potential justifications for the existence of a 'disability music scene' and the community ensembles within it; and for highlighting, or at least not attempting to downplay, visual impairment as a musician.

Nonetheless, we found evidence that, for some of these musicians, various issues could take a rather different turn. Certain negative views of Inner Vision and the Paraorchestra were expressed, primarily and perhaps not surprisingly by interviewees who had forged successful careers predominantly with sighted musicians. They believed 'disability' took the focus away from the quality of the musical product achievable by visually impaired people. For some respondents, particularly those who played down disability as marketable, there was a question mark as to whether or not promotion through visual impairment tends to come from sighted outsiders, such as promoters, website designers, and others, and thus is more to do with sighted people's expectations and the traditions of blind musicianship we mentioned earlier, than with their personally-felt perspectives.

One sight-impaired interviewee had been a member of disabled community music ensembles in the 1980s and was also a member of Inner Vision. S/he (anon.) was reticent, evading our questions on pros and cons of the orchestra with responses like this:

Well, I'm involved in Inner Vision, so I'm not against being in a blind band [long pause]. Hmm ... [long pause] I don't know really. Sorry, not very [the interviewee turns the conversation to another subject]. (Anon. interview, UK)

His or her partner, who was in the background during our conversation, and to whom s/he redirected some dialogue, forwarded this message by email later that day:

When [name removed for confidentiality] was involved with Disability Arts [he or she] was berated by some for working with able-bodied musicians! It was not always a supportive environment and [he or she] had opprobrium for being less disabled than they assumed [he or she] was: very hierarchical about disability and often po-faced. That was the 1980s though and it was a po-faced decade. (Email headed 'My relevant interjection')

We stated on the questionnaire: 'It is positive to create musical activities (e.g., ensembles, workshops, concerts) involving adults who all have a disability, including visual impairments'. On a five-point rating scale with 145 responses from 'strongly disagree' to 'strongly agree', the mean score was 3.61, situated between 'neither disagree nor agree' and 'agree' $(\mathrm{SD}=1.08)$. It was clear that not every visually impaired person was in favor of such endeavours; indeed, 10.99 per cent $(n=21$ of the total of 191 questionnaire responses) disagreed with the statement, 19.37 per cent (37) were uncertain and 24.08 per cent (46) did not answer.

Many of the musicians with whom we spoke expressed mixed feelings about the position of visual impairment in grouping together. Some simply did not make their visual impairment in any way obvious. Amelia (pseudonym), who was a partially sighted electric bass and rock musician, would be an example. She never mentioned her sight impairment in promotional materials or when networking or communicating with other musicians. We first met her at the UCL Institute in 2011; her 
independent mobility around our building appeared to be trouble-free and there were no physical cues of her sight impairment that we could perceive.

Despite performing as a guitarist in Inner Vision, Rikki Jodelko was eager not to commit to a 'disabled musical identity':

I don't disguise the fact that I'm blind; neither do I promote it, I suppose. You know, I'm quite comfortable with my blindness. That doesn't mean to say that I use it. I might use it to get a seat on the tube, you know, 'Any spare seats?' [laughs], but 'Any gigs going? I'm blind, you know’. No, I don’t think so. (Rikki Jodelko, guitarist, blind; interview, UK).

Liz Hargest was unsure about the merits of the Paraorchestra:

I've just become part of the Para-orchestra and I've got really mixed feelings, if I am honest. I am not sure whether I want to be there or I don't ... I think it depends where it is breeding from. If it's bred from the fact that it's a group of musicians who all fight against the odds to be where they are, to create what they do, that's a good thing, but, if the orchestra is going to be plugged on the disability aspect of it-I think it's like anything you create, it can be good or bad and I haven't been in it long enough to know what I feel. Unless I try it, unless I experience it for myself, I won't know ... I mean it's like the Paralympics, isn't it? I mean all those people who achieve in the Paralympics wouldn't be able to achieve those things against fully-able athletes. I think the same is the case for a lot of musicians in the Para-orchestra. They would not be able to take part in proper orchestras because of the disabilities that they have. (Liz Hargest, flautist and instrumental teacher, blind; interview, UK)

Some of our interviewees were hesitant to connect their musical lives to their disability at all, including being dismissive. Some were also eager to stress that they had no greater aural ability or musical skill than the sighted. Yet at times they nevertheless promoted themselves through it. In contrast, others accepted, with considerable self-assuredness, and with no apparent dismay we add, that there was no way in which to circumvent a connection between their disability and music (mostly, of course, these respondents were those who were visually impaired from birth and for whom disability was patent). This was simply their fate.

It's been slightly difficult because I've tended to resist being typecast. Although I haven't succeeded, 'cause I usually end up doing a few Stevie Wonder tunes (laughs), 'cause people love them and I enjoy doing them ... I remember a drunk once saying 'Do you practise Stevie Wonder's head movements in front of a mirror' and, in a rare moment of presence of mind, I said 'I don't know—what's a mirror (laughs)?' That stuff's just funny but-There is something about blindness, much as people might like to-I think it is very simple (laughs); you just concentrate on what you have. The world is a fairly audio-tactile place for me; I'm not going to be painting portraits. (Reg Webb, jazz pianist, pop musician, and composer, blind; interview, UK)

There were sub-groups with harmonious positions amongst the musicians we interviewed, particularly within those who clubbed together in disabled ensembles like Inner Vision, the My Sight Choir, and the Paraorchestra. We are not suggesting, needless to say, that every member of a disabled orchestra, band, or choir holds exactly the same beliefs, but there were certainly intersections in the thinking of Baluji Shrivastav, Linda Shanson, and Ziad Sinno, for instance. Some of the musicians in those groups were less politically motivated, though. They merely took advantage of the opportunities provided, just to meet with friends, socialize, share information and network, or to get additional performances, without subscribing to all the specified politics. We should remember that the pool of visually impaired musicians, certainly in the UK, is relatively limited; many know each other. As James Risdon noted: 
My recent involvement with Para-orchestra ... has challenged me to consider many of the issues in a new light. Of the disabled musicians involved, eight were blind or partially sighted. Of these eight, there was a wide range of experiences and attitudes, broadly speaking and generalizing from: 'I've found solutions to problems and got on with it; if you're good enough there are no barriers' to 'There aren't enough opportunities for blind musicians and we need more help'. I suppose where you are on this scale depends on many factors, but my thinking is that they are certainly not all musical. (James Risdon, recorder, blind; email, UK)

Some interviewees expressed very strong feelings opposed to any identification of visual impairment as a disability group, or as an individual. One respondent (who wished this comment to be anonymous) argued as follows:

The idea of an entirely visually-impaired band is terrible; there are not enough blind musicians about; bands should be grouped together and judged on the musicianship of their members and not their disability. If we do things any other way, all we do is show everyone how bad disabled people are at music.

This person's long career had been in the 'mainstream industry' (quote) and seldom entailed performing, recording, or working with other visually impaired people, let alone in community ensembles. During the interview (and afterwards), there was a tangible sense of a desire to distance him or herself from the notion of 'disability arts'.

Geoff Long, a retired professional pianist, singer, and entertainer, explained his position:

I did a job for an agent called [name removed] once, quite a good gig. I was in a four-piece rock band at the time; three of us were blind; the drummer could see. We didn't tell him we were blind. I didn't see the point really. You know, it was a commercial gig. There wasn't such a thing as the 'disability arts scene' then. So, you either played professionally or-You know, there was none of this giving people 200 quid for gigs, people who should have been thrown out of a Butlin's [a traditional British holiday camp with family entertainment] because they're useless. I've seen so many really useless disabled acts and the only reason they get paid is because they are doing 'disability gigs', which are rubbish. Obviously, I am totally blind; I absolutely haven't got a problem with that; I don't hide it. I mean, we were the first blind rock band, as far as I know. In the 1970s, we had a recording contract with EMI. We didn't publicise the fact that we were blind but, obviously, when people saw us, they could see that, obviously, at least two of us were blind. Visual impairment never had anything to do with me getting work. Now, I'm not saying that, once I got the work- You know, people don't expect blind people to be confident and, you know, crash through life. They expect them to have carers and bloody guiders and whatever. I wasn't into all that bollocks; I just crashed through life and got on with it; and did it. (Geoff Long, pianist and pop singer, blind; interview, UK)

Similarly, playing down factors of mobility, discrimination, marginality, and so forth, Joe Buck thought musical success for the visually impaired was simply a matter of ability:

You either have it or you don't! You know there are limitations when you don't have sight, as you said like Braille, but, in different ways, there is no limit. You almost have an edge when you lose your sight because you hear so much better. So it's a love-hate relationship with my blindness. (Joe Buck, film and television composer, partially sighted; interview, US)

If there were no community music groups for the blind and partially sighted, however, many would face challenges in terms of the independent mobility required to reach rehearsals and concerts, or they would find sourcing the help of sighted guides or supporters difficult. Support of that type can often be obtained through the networks associated with these ensembles. Moreover, this would be worse for 
those who experience sight-loss later in their lives; these musicians are adjusting to their new sensory circumstances and must learn quickly about mobility and support from their community, governments, and charities. Even respondents we met who were blind at birth or early in their lives were on a continuum from 'dependence' to 'independence', with some always relying on sighted help for navigation (e.g., from friends or spouses) and others traversing busy London streets independently with ease using GPS on their digital Braille devices. Furthermore, we must ponder the accessibility of the musical approaches used in sighted music groups, which brings into play a range of considerations. For example, reading sheet music (or obtaining it in Braille or large print if one of those is the person's preferred medium) or memorizing it, following a conductor, making eye contact with other performers (or one's inability to do so), learning stagecraft, moving around a stage without knocking into objects, and so on. For the visually impaired person, then, encircling all this is the issue of confidence in one's ability to participate, which arises from many biographical factors (e.g., parents' attitudes and upbringing, experiences in schooling and other formal education, music in informal contexts, the point at which someone became visually impaired, wider personality, etc.). It is clear that groups like Inner Vision or the Paraorchestra come together in recognition of these concerns; for example, they create situations where 'funding goes into facilitating travel and accommodation for ... players, many of whom are dependent on fulltime personal assistants and travel with wheelchairs and other special equipment ... often a major challenge of logistics and accessibility'. ${ }^{27}$

\section{Reflections}

It may be tempting to define a 'community' as a group of people with a common purpose (Johnson, Headey, \& Jensen, 2005). However, as Schippers \& Bartleet (2013, p. 455) observe, all-encompassing definitions come from 'sometimes biased specifics that would not necessarily characterize all community music activities ("creating rather than recreating music"; "musical activity as a reaction against formal music education")'. While there are certainly problems with assigning a conclusive definition, largely due to the wide variety of practices and aims in community music groups, our experiences with visually impaired musicians were in keeping with some of the available definitions such as Cahill's (1998) consideration of community music as organized by vested social groups, rather than 'top-down' activities delivered to them; and community musicians are also not 'just a group of amateurs having a good time' (p. 7). Participants 'sign up to community music projects because they want to be worked with rather than worked on' (Higgins, 2012b, p. 159). This is about the 'agency' of social groups.

In accord with that slant, out of those we have discussed, the Inner Vision Orchestra in particular has resulted from blind and partially sighted musicians themselves wanting to find accessible ways to participate in music; that is, the ensemble was not founded by a sighted person or people, or indeed organizations dominated by them, who then decided there was a need to be addressed in a marginalized, disempowered or overlooked group. Higgins (2006) writes of community music as 'an active resistance towards institutionalized structures' (p. 7); and in (2007) he notes that community music found its footing in the 1970s as 'an expression of cultural democracy, a doctrine of empowerment and a tool for action ...' (p. 281); and Letts (1997) writes of 'programs that, unconstrained by any educational bureaucracy, have found solutions that fit the needs of particular communities' (p. 27). Again, in highlighting 'activism', sidestepping 'educational bureaucracy' and 'finding solutions', we might note that Inner Vision members perceived other opportunities for musical participation to be inadequate, such as those available to sighted counterparts, including for lifelong learning (Myers, 1995, 2008; Roulston, 2010).

Similarly, the Paraorchestra is about recognizing the practical problems associated with being a disabled musician (e.g., concerning travel, score media use, genres, and approaches) and finding solutions to foster participation. Visually impaired choirs naturally exploit musical approaches that do 
not require their members to read sheet music too (i.e., many amateur choirs with only sighted members learn by ear). All these ensembles create a space for confident artistic endeavour, belonging, and a sense of community. Ansdell (2014) notes that, although organizers of community music often note therapeutic effects, a significant distinction between community music and music therapy lies in its communal as opposed to individualized contexts. Koopman (2007) writes that community music contributes to well-being as it 'helps people to share experiences and to understand each other' ( $p$. 153; also see Jones, 2014). By 'providing opportunities for creativity and self-expression, [it] help[s] people to develop their artistic abilities and identity. Self-esteem and self-confidence are seen as significant outcomes of community music' (Koopman, 2007, ibid.).

From the perspective of a sighted person, it might seem that grouping musicians according to a disability, vision-related or otherwise, is only a positive idea: it builds networks of people who might share information, or support each other. However, practical benefits aside, an implied need for support is already value-laden, with connotations of marginality, inequality, lack of social integration. For some, seeing or presenting themselves in that way adds to, or creates problems, rather than providing solutions. This need for activism and its underlying logic sets an uncomfortable tone for some visually impaired musicians, then, including those who choose not to perform with ensembles like Inner Vision, My Sight, the Paraorchestra, or the Salisbury Blind Choir; they feel that grouping together or presenting music through disability is destructive to social inclusion because it accents difference far too emphatically and pollutes quality music-making.

It seems that the worthiness of disability arts can be seen to revolve around two main positions. On one side of the debate, there is the primacy of the musical product above all else. It is possible, of course, that evasiveness to our questions on 'disability music', or seemingly inert positions or antagonistic remarks on it, come from the belief that 'playing up disability' means 'playing down ability'. Thus, for this sub-group, we should avoid fixating on dis-ability and dis-abled musical groups, with the concurrent assumption that, since they belong to a minority with limited numbers, 'disabled ensemble' equates to a low musical standard. In turn, community music groups linked to disabilities can lead to the development of negative perceptions in wider society. For these protagonists, 'If you are good enough, there are no barriers'. Indeed, the concept of a disabled community choir or a 'blind' orchestra is counterproductive. However, it must be said that those who expressed views most forcefully in line with this were often the professionals in our study who had formed successful music careers - significantly, without needing to engage with disabled ensembles.

As we have seen, many on the opposing side of the debate will parry that current opportunities are limited, and there is, in fact, social isolation, underrepresentation in musical participation, in addition to the practicalities of working in certain contexts and musical traditions. They would say that their visually impaired ensemble members and colleagues are indeed equal, sometimes superior, in musical terms to sighted musicians in their musical skills and accomplishments. Owing to that, this perspective suggests, the former orientation is unfounded. Advocates like Baluji Shrivastav, Linda Shanson, Charles Hazlewood, Paul Mugambi, and others consider a pressing need both to raise awareness of disability in music, and to create workable, accessible opportunities, communities, and strong networks that are presently scant. Within this latter side of the argument, we witnessed Baluji and Linda's stated 'process' (earlier in this chapter), whereby, by nurturing confidence and supporting independent living amongst visually impaired musicians, greater integration into sighted musical communities will occur naturally. This will take time of course, and the extent to which the Inner Vision Orchestra, the Paraorchestra, and other semi-professional, community, or amateur groups based around visual impairment or other disabilities have impacted, or will impact, upon barriers for visually impaired musicians remains unclear. This may be a focus for future researchers, media, and policymakers. 
So was discrimination the sole justification for 'disability arts'? Some of our interviewees stated 'musical process' reasons for inequality with the sighted, by which we mean differences in the way they learned, rehearsed, or performed music, including the use of enlarged notation, Braille music, aural methods and other approaches, plus the consequent time required to access, absorb, and reproduce repertoire. These were linked in different ways to the musical traditions of particular genres, particularly the dominance of print notation and sight-reading in classical music, which presented particular challenges to musical participation in that area. For the Braille music user, for instance, the symphony orchestra might require additional time in sourcing scores and learning them; sight reading may be challenging or impossible too.

So what else has generated visually impaired community music ensembles? Despite references to isolation and lack of opportunity, it was interesting to us that by and large, technology use was challenging the isolation, mainly through e-bulletins, newsgroups, blogs, and the activities of a range of organizations. Nonetheless, some interviewees did experience isolation from other musicians, with some stark examples: one UK musician (interview, anon.) had recently lost his or her sight. He or she was even unaware that the RNIB had an advisory service for music and activities to attend. This was strongly felt as isolation. It was perhaps a function of the point at which he or she experienced substantial sight-loss; and it formed a potential transition point from the sighted world to the practice of visually impaired music-making - a clear 'marker' to us of a visually impaired subcultural group in music and, in turn, that is a reason for community music ensembles coming into being. Here, to contrast with this respondent's experience, we note that those blind from birth or with congenital conditions are typically far more embedded in, or, at least, aware of, other blind musicians, their surrounding culture, the social politics, and available opportunities.

We present the views here as a few representations of like-minded or differently minded stakeholders. For those wishing to create musical outreach or wanting to shape community music programmes for visually impaired people in our communities, what this does strongly highlight is that if mismanaged, events can be hugely discordant with the self-identities of some participants. That might happen, for instance, if beginner visually impaired musicians are grouped with professional-standard counterparts without prior planning and awareness; or those who work primarily from Braille with ear players; or if musical genres with different learning, rehearsal, and performing traditions are not considered within plans. Any misalignment of the philosophies of sighted and visually impaired stakeholders in such ventures might simply result in disengagement and, ultimately, failure. As Crichton (1992) observes 'too often, disabled people have had their experiences decided for them, sometimes by other people's limiting and negative assumptions of what is possible' (pp. 213-214). We feel there is great value in exploring the views of visually impaired musicians themselves, to better understand these musical participants' needs and orientations, and to help narrow the perceptive divide.

\section{Reflective questions}

1. How are visually impaired musicians' identities, and the manner in which they present themselves, shaped by their historical backcloth of worldwide traditions?

2. To what extent does the accessibility of the musical opportunities they encounter shape their participation and trajectories as musicians? How is that accessibility affected by, for example, the media used, the musical approaches adopted, the independent mobility required, the confidence exhibited in the visually impaired person, and the experience and surrounding attitudes presented by others?

3. 3. In what ways and for what reasons do some visually impaired musicians perceive marginalization and underrepresentation in music?

4. In terms of social integration, what is the nature of possible benefits and downsides to ensembles comprised entirely of disabled or visually impaired musicians? 
5. How might community music for visually impaired people best be formed?

\section{Key Sources}

Baker, D., \& Green, L. (2017) Insights in Sound: Visually Impaired Musicians' Lives and Learning. London: Routledge.

Baker, D., \& Green, L. (2016) Notions of schooling, pedagogy, and notation in the lives of visuallyimpaired musicians. Research Studies in Music Education, 38(2), 193-219.

Baker, D. (2014). Visually-impaired musicians' narrative insights: Childhood, lifelong learning and musical participation. British Journal of Music Education, 31(2), 113-135.

Lubet, A. (2011) Music, Disability, and Society. Philadelphia, PA: Temple University Press.

Straus, J. N. (2011) Extraordinary Measures: Disability in Music. New York: Oxford University Press.

\section{Acknowledgements}

We are extremely grateful for the financial support of the Arts and Humanities Research Council (AHRC), in addition to guidance from the Music Advisory Service of the Royal National Institute of Blind People (RNIB) (Sally Zimmermann and James Risdon). Our sincere gratitude also goes to Robert Mitchell, our project administrator at the UCL Institute of Education, and to Dr Maria Vraka for transcribing a huge quantity of interview audio. 'Visually-impaired musicians' lives' also had an advisory panel, which consisted of Peter Bosher, Soundlinks Ltd.; Jacqueline Clifton MBE, fellow in Visual Impairment and Music, Royal College of Music, London; Dr Anthony Gritten, Head of Undergraduate Programmes; and Julian West, Open Academy, Royal Academy of Music, London; Kevin Kern, a visually impaired musician and Official Steinway Artist from the United States; Lord Colin Low of Dalston CBE, RNIB; Lydia Machell, Prima Vista Braille Music Services; and Miss Vasuki Sivagnanavel, Consultant Ophthalmic Surgeon, Royal Eye Unit, Kingston Hospital, London. We wish to convey our sincere appreciation to all of these panel members in addition to Dr Charles Ford and Thuy Hoang for reading drafts. Finally, we are grateful to the many visually impaired musicians who contributed their fascinating stories to this project.

\section{References}

Ansdell, G. (2014). Revisiting 'Community music therapy and the winds of change' (2002): An original article and a retrospective evaluation. International Journal of Community Music, 7(1), $11-$ 45 .

Armstrong, P. (1987). Qualitative strategies in social and educational research: The life history method in theory and practice (Newland Paper, No. 14). Hull, UK: School of Adult and Continuing Education, University of Hull.

Atkinson, R. (1998). The Life Story Interview (Qualitative Research Methods Series, No. 44). Thousand Oaks, CA: Sage.

Atkinson, R. (2001). The life story interview. In J. F. Gubrium \& J. A. Holstein (Eds.), Handbook of Interview Research: Context and Method (pp. 121-140). Thousand Oaks, CA: Sage.

Baker, D. (2014). Visually-impaired musicians' narrative insights: Childhood, lifelong learning, and musical participation. British Journal of Music Education, 31(2), 113-135.

Baker, D., \& Green, L. (forthcoming). Perceptions of schooling, pedagogy, and notation in the lives of visually-impaired musicians. Research Studies in Music Education. 
Barrett, M., \& Stauffer, S., eds. (2009). Narrative Inquiry in Music Education: Troubling Certainty. Heidelberg: Springer.

Barrett, M., \& Stauffer, S., eds. (2012) Narrative Soundings: An Anthology of Narrative Inquiry in Music Education. Heidelberg: Springer.

Bartleet, B. L., Dunbar-Hall, P., Letts, R., \& Schippers, H. (2009). Sound Links: Community Music in Australia. Brisbane, Australia: Queensland Conservatorium Research Centre.

Batterson, J. A. (1998). Blind Boone: Missouri's Ragtime Pioneer. Columbia, MO: University of Missouri Press.

Bertaux, D., ed. (1981). Biography and Society: The Life History Approach in the Social Sciences (Studies in International Sociology, No. 23). Beverly Hills, CA: Sage.

Bertaux, D., \& Kohli, M. (1984). The life story approach: A continental view. Annual Review of Sociology, 10, 215-237.

Cahill, A. (1998). The Community Music Handbook: A Practical Guide to Developing Music Projects and Organizations. Sydney: Currency Press, in association with the Music Council of Australia.

Casey, K. (1993). I Answer with My Life: Life Histories of Women Teachers Working for Social Change. New York: Routledge.

Clerk, C. (2014). The Inner Vision National Tour, England, Jun-October 2013. London: Baluji Music Foundation.

Cohen, L., Manion, L., \& Morrison, K. (2000). Research Methods in Education (5th edn.). London: Routledge and Falmer Press.

Crichton, L. (1992). 'Music for everyone?' British Journal of Music Education, 9(3), 211-215.

De Ferranti, H. (2009). The Last Biwa Singer: A Blind Musician in History, Imagination and Performance. Ithaca, NY: Cornell University Press.

Dimatati, M., Heaton, P., Pring, L., Downing, J., \& Ockelford, A. (2012). Exploring the impact of congenital visual impairment on the development of absolute pitch using a new online assessment tool: A preliminary study. Psychomusicology: Music, Mind and Brain, 22(2), 129-133.

Dollase, R. H. (1992). Voices of Beginning Teachers: Visions and Realities. New York: Teachers College Press.

Fuqua, C. S. (2011). Alabama Musicians: Musical Heritage from the Heart of Dixie. Charleston, SC: The History Press.

Glesne, C. E., \& Peshkin, A. (1992). Becoming Qualitative Researchers: An Introduction. New York: Longman.

Gregory, I. (2003). Ethics in Research. Continuum Research Methods Series, R. Andrews (Ed.). London: Continuum.

Groemer, G. (2012). The Spirit of Tsugaru—Blind Musicians, Tsugaru-Jamisen, and the Folk Music of Northern Japan (with the Autobiography of Takahashi Chikuzan) (2nd edn.). Aomori Prefecture, Japan: Tsugaru Shobo Hirosaki.

Hamilton, R., Pascual-Leone, A., \& Schlaug, G. (2004). Absolute pitch in blind musicians. Neuroreport: Auditory and Vestibular Systems, 15(5), 803-806.

Harrah, M. (2004). Blind Boone: Piano Prodigy. Minneapolis, MN: Carol Rhoda Books. 
Higgins, L. (2006). Boundary-walkers: Contexts and concepts of community music (PhD dissertation), University of Limerick, Ireland.

Higgins, L. (2007). Acts of hospitality: The community in community music. Music Education Research, 9(2), 281-292.

Higgins, L. (2012a). Community Music: In Theory and in Practice. New York: Oxford University Press.

Higgins, L. (2012b). One-to-one encounters: Facilitators, participants, and friendship. Theory Into Practice, 51(3), 159-166.

Huberman, M. (1993). The Lives of Teachers (tr. J. Neufeld). New York: Teachers College Press.

Huberman, M., \& Marti, J. (1993). Beginning teaching. In A. Hargreaves (Ed.), The Lives of Teachers (pp. 194-213). New York: Teachers College Press.

Johnson, D., Headey, B., \& Jensen, B. (2005). Communities, Social Capital, and Public Policy: Literature Review. Canberra: Australian Government, Department of Family and Community Services.

Jones, J. A. (2014). Health musicking in a skiffle steel orchestra: Thoughts on collaboration between community music therapy and medical ethnomusicology. International Journal of Community Music, 7(1), 129-144.

Kononenko, N. (1998). Ukrainian Minstrels: And the Blind Shall Sing. New York: M. E. Sharpe.

Koopman, C. (2007). Community music as music education: On the educational potential of community music. International Journal of Music Education, 25(2), 151-163.

Lababidi, L., \& El-Arabi, N. (2002). Silent No More: Special Needs People in Egypt. Cairo: American University in Cairo Press.

Letts, R. (1997). Music: Universal language between all nations? International Journal of Music Education, 29(1), 22-31.

Lewis, O. (1961). The Children of Sánchez. New York: Vintage.

Lubet, A. (2011). Music, Disability, and Society. Philadelphia, PA: Temple University Press.

Ludlow, J. (1995). Blind to the facts: An exploration of the needs of the blind and visually-impaired musician. Report for Inner Vision, A. Meadows (Ed.). London: Inner Vision Company.

McLucas, A.-D. (2010). The Musical Ear: Oral Tradition in the USA. Farnham, Surrey: Ashgate.

Munro, P. (1998). Subject to Fiction: Women Teachers' Life History Narratives and the Cultural Politics of Resistance. Buckingham, UK: Open University Press.

Myers, D. E. (1995). Lifelong learning: An emerging research agenda for music education. Research Studies in Music Education, 4(1), 21-27.

Myers, D. E. (2008). Lifespan engagement and the question of relevance: Challenges for music education research in the twenty-first century. Music Education Research, 10(1), 1-14.

Ockelford, A. (2007). In the Key of Genius: The Extraordinary Life of Derek Paravicini. London: Hutchinson. 
Ockelford, A., \& Matawa, C. (2009). Focus on Music 2: Exploring the Musical Interests and Abilities of Blind and Partially-Sighted Children with Retinopathy of Prematurity. London: Institute of Education, University of London.

Ockelford, A., Pring, L., Welch, G. F., \& Treffert, D. (2006). Focus on Music: Exploring the Musical Interests and Abilities of Blind and Partially Sighted Children with Septo-Optic Dysplasia. London: Institute of Education, University of London.

Ottenberg, S. (1996). Seeing with Music: The Lives of Three Blind African Musicians. Washington, DC: University of Washington Press.

Roulston, K. (2010). 'There is no end to learning': Lifelong education and the joyful learner. International Journal of Music Education, 28(4), 341-352.

Rowden, T. (2009). The Songs of Blind Folk: African American Musicians and the Cultures of Blindness. Ann Arbor: University of Michigan Press.

Ryen, A. (2004). Ethical issues. In C. Seale, G. Gobo, J. F. Gubrium, \& D. Silverman (Eds.), Qualitative Research Practice (pp. 230-247). London: Sage.

Schippers, H., \& Bartleet, B.-L. (2013). The nine domains of community music: Exploring the crossroads of formal and informal music education. International Journal of Music Education, 31(4), 454-471.

Shaw, C., ed. (1930). The Jack-Roller. Chicago: University of Chicago Press.

Sikes, P. J. (1985). The life cycle of the teacher. In S. J. Ball \& I. F. Goodson (Eds.), Teachers' Lives and Careers (pp. 27-60). Lewes, East Sussex, UK: Falmer Press.

Silverman, D. (2000). Doing Qualitative Research: A Practical Handbook. London: Sage.

Silvers, A., Wasserman, D., \& Mahowald, M. B. (1998). Disability, Difference, Discrimination:

Perspectives on Justice in Bioethics and Public Policy. Lanham, MD: Rowman and Littlefield.

Southall, G. H. (1999). Blind Tom, the Black Pianist-Composer: Continually Enslaved. Lanham, MD: Scarecrow.

Sparkes, A. C. (1994a). Life histories and the issue of voice: Reflections on an emerging relationship. International Journal of Qualitative Studies, 7(2), 165-183.

Sparkes, A. C. (1994b). Understanding Teachers: A Life History Approach. Educational Research Monograph Series, H. A. Radnor (Ed.). Exeter, UK: Research Support Unit, University of Exeter.

Thomas, W. I., \& Znaniecki, F. (1919). The Polish Peasant in Europe and America: Monograph of an Immigrant Group (Vol. 3, 'Life record of an Immigrant'). Boston, MA: Gorham Press (Richard G. Badger).

Thomas, W. I., \& Znaniecki, F. (1927). The Polish Peasant in Europe and America. Chicago: University of Chicago Press.

Veblen, K. (2005). Community music and praxialism. In D. J. Elliott (Ed.), Praxial Music Education: Reflections and Dialogues (pp. 308-328). New York: Oxford University Press.

Veblen, K., \& Olsson, B. (2002). Community music: Toward an international overview. In R. Colwell \& C. Richardson (Eds.), The New Handbook of Research on Music Teaching and Learning (pp. 730753). New York: Oxford University Press. 
Welch, G. F. (1988). Observations on the incidence of absolute pitch (AP) ability in the early blind. Psychology of Music, 16(1), 77-80.

\section{Notes:}

(1.) Our findings are from 'Visually-impaired musicians' lives', or VIML, a research project funded by the Arts and Humanities Research Council (Grant ref. AH/K003291/1, 2013-2015) at the UCL Institute of Education, London. This was supported by the Royal National Institute of Blind People (RNIB), Britain's major charity for visually impaired (i.e., blind and partially sighted) people, and the Royal Academy of Music, London. VIML investigated lives in a broad sense, and aspects of the project are discussed in different publications (e.g., music teaching and learning inside and outside formal education; the role of the family; challenges and possibilities presented by Braille, accessible music information technologies, and other means of musical transmission; participation in musical performance, composition, and other activities; the professional music industry; and more). Parts of this chapter have been adapted from the book Insights in Sound: Visually-Impaired Musicians' Lives and Learning by David Baker and Lucy Green (in preparation). The pilot study is reported in Baker (2014) and issues surrounding schooling, pedagogy, and notation in Baker and Green (forthcoming). In VIML, we offered to use pseudonyms but, as with this chapter, many respondents gave us permission to use their real names. Ethical procedures in the research followed the British Educational Research Association (BERA) and UCL Institute of Education guidelines.

(2.) For more information on these ensembles of visually impaired musicians, please refer to $\mathrm{Al}$ Monitor: http://www.al-monitor.com/pulse/originals/2014/05/egypt-blind-women-orchestra-nouramal.html\#; YouTube, 'Blind Egyptian Female Orchestra Entralls

Audience': https://www.youtube.com/watch?v=A-fC4htwki0 ; BBC News, 'The Sounds of Egypt's Blind Orchestra':http://www.bbc.co.uk/news/world-middle-east-20008432 (Al Nour Wal Amal Chamber Orchestra); Facebook, 'Korean Traditional Music Orchestra of the

Blind': https://www.facebook.com/media/set/?set=a.534945546541154.1073741826.1094133124277 15\&type $=3$; Fox News, 'World's First Symphonic Band of Blind Musicians Shines

Light': http://www.foxnews.com/lifestyle/2011/12/01/worlds-first-symphonic-band-blind-musiciansshines-light.html(Argentinian National Symphony Blind Band); and the Indian Express, 'An Afternoon with the St. Louis Blind

Orchestra': http://www.newindianexpress.com/cities/chennai/article551407.ece (St. Louis Blind Orchestra). The term 'Kollywood' is a blend of 'Kodambakkam', India, where the industry is based and 'Hollywood'.

(3.) Refer to The Guardian, 'The World's First Visually-Impaired Ukulele Band? What Next for a School with Dreams?': http://www.theguardian.com/lifeandstyle/2014/sep/12/the-worlds-firstvisually-impaired-ukulele-band-what-next-for-a-school-with-dreams

(4.) For information on Create, refer to LSO Create: http://lso.co.uk/lso-discovery/community/lsocreate

(5.) Voluntary 'registration' in the United Kingdom requires acquiring a Certificate of Visual Impairment (CVI) from an ophthalmologist and has benefits, such as practical support from social services departments; a reduced television licence fee; getting a disabled person's railcard; tax allowance; Disability Living Allowance (DLA); or free National Health Service (NHS) sight tests. Visual acuity and fields (the horizontal and vertical compass of sensations to the eye) are tested by the ophthalmologist. For more information and the benchmarks for registration, refer to 'Registering your sight loss' on the Royal National Institute of the Blind website (and linked pages)

at http://www.rnib.org.uk/livingwithsightloss/registeringsightloss/Pages/register_sight_loss.aspx

(6.) Visually impaired people can access electronic media (e.g., Web pages, software applications, email, and other digital file formats) with 'screen reader' software, which produces audio (a synthetic 
voice) from elements and text normally viewed by users. The navigation of, say, webpages is by keystrokes. Text-to-speech software is sometimes also used in conjunction with a hardware device, such as a refreshable Braille display. James Risdon, a severely sight-impaired member of our team tested our website and other electronic materials using two popular screen readers, JAWS (Job Access with Speech) and NVDA (Non-Visual Desktop Access).

(7.) There is a tradition of biographical research in education and the social sciences. For texts on or using biographical methods, read e.g., Thomas and Znaniecki (1919, 1927), Shaw (1930), Lewis (1961), Bertaux (1981), Bertaux and Kohli (1984), Sikes (1985), Armstrong (1987), Dollase (1992), Casey (1993), Huberman (1993), Huberman and Marti (1993), Sparkes (1994a, 1994b), Munro (1998), and Barrett and Stauffer (2009, 2012).

(8.) The eye conditions of our respondents included cataracts, diabetic retinopathy, glaucoma, high myopia, Leber's congenital amaurosis, macular degeneration, microphthalmia, nystagmus, ocular albinism, retinal detachments, retinitis pigmentosa, retinoblastomas, retinopathy of prematurity, Stargardt's disease, uveitis, and some conditions resulting from accidents. Respondents also mentioned secondary eye-health problems such as astigmatism, cataracts, glaucoma, nystagmus, and retinal detachments.

(9.) Bhangra refers to an upbeat popular music style, which became prevalent in Britain in the 1980s as a cultural product of young people of the Punjabi diaspora. It typically features the dhol (an Indian percussion instrument).

(10.) We used the British Educational Research Association's (BERA) ethical guidelines which can be downloaded from http://www.bera.ac.uk/ or from the British Psychological Society's website http://www.bps.org.uk/, in combination with the Institute of Education, University of London's ethical procedures, which can be found at http://www.ioe.ac.uk/about/policiesProcedures/41899.html

(11.) Refer to Baluji Music Foundation at http://balujimusicfoundation.org/index.php. The website states, 'We are an inclusive organisation and encourage participation with people from different cultural perspectives, and we especially welcome people who are differently abled'.

(12.) Refer to Baluji Music Foundation, 'Inner Vision Orchestra \& Workshops': http://balujimusicfoundation.org/about_us/inner-vision.php

(13.) See the British Paraorchestra website at http://www.paraorchestra.com/

(14.) Refer to http://www.paraorchestra.com/

(15.) 'Paralympics 2012: Meet the British Paraorchestra' by Peter Stanford, from Telegraph online, 11 September 2012: http://www.telegraph.co.uk/sport/olympics/paralympic-sport/paralympicsgb/9533666/Paralympics-2012-meet-the-British-Paraorchestra.html

(16.) 'British Paraorchestra—The Story So Far': http://www.paraorchestra.com/events.php

(17.) On community music, also refer to Bartleet et al., 2009;

Higgins, 2006, 2007, 2012a, 2012b; Veblen, 2005; and Veblen and Olsson, 2002.

(18.) Louis Braille (1809-1852) developed a tactile language consisting of raised dots in rectangular cells in the nineteenth century. Braille can be embossed onto paper or light card, or used for every day labelling or signage; or it can be produced by hardware devices such as refreshable Braille displays in computing. Braille was an organist and transmission can be divided into 'literary Braille', used for reading and writing (as a substitute for printed or handwritten text), and 'Braille Music', an alternative to printed music notation. Braille music transcriptions of stave notation can be acquired from various services, but this can be costly and take considerable time. Optical Music Recognition (OMR) using 
scanners and software like Goodfeel is easing access in creating Braille from print, as are services such as Lydia Machell's Prima Vista Braille Music Services. Lydia has created software and made agreements with major music publishers, so that consumers can download a brf (Braille Ready Format) digital file of music notation from her website. 'Modified stave notation' refers to stave notation whereby elements such as note-heads are altered in size, or the background colour is changed, and the stave lines thickened, and so on. Software such as MuseScore is able to make these adaptations.

(19.) McLucas (2010) uses the term 'oral traditions' to denote 'those aspects of music that are passed down by humans teaching one another the art form, whether in person of by means of recordings, radio, television, or other non-written means ... [and] also refers to the kinds of composition that occur completely without reference to written notation; that is, the creative as well as re-creative forms of oral tradition' (p. 2).

(20.) For information on UK Access to Work grants, see Gov.UK, 'Get Help at Work If You're Disabled or Have a Health Condition': https://www.gov.uk/access-to-work/what-youll-get. The money can be used for adaptations to equipment, fares to work, a support worker, disability awareness training for colleagues, and so on.

(21.) This quotation comes from Ron Brownlow of the Taipei Times at http://www.brownpapertickets.com/event/434220 and is also included in Pictures from the Piano-An Evening with Kevin Kern, to advertise a concert in Duluth, Atlanta, on Friday, 11 October 2013. The same quotation is used by Kevin at 'Kevin Kern — pianist, composer, recording artist', Piano World [blog], 13 September

2013: http://www.pianoworld.com/forum/ubbthreads.php/topics/2149643/Kevin\%20Kern\%20\%20Pianist,\%20Composer.html

(22.) Kevin is described as 'the Stevie Wonder of classical music' by Brownlow in 'Kevin Kern Plays the Music of Light' in the Taipei Times online, 26 May

2006: http://www.taipeitimes.com/News/feat/archives/2006/05/26/2003310132/2

(23.) 'Kitchen Caliente' by Jammin' Joe Buck can be viewed on

YouTube: http://www.youtube.com/watch?v=XgxNNsA2xhc

(24.) 'Never, Never Ever Give Up' by Paul Mugambi is available on

YouTube: http://www.youtube.com/watch?v=O_dS2qHrbhI

(25.) 'Never Give Up!' can be seen on

YouTube: http://www.youtube.com/watch?v=O_dS2qHrbhI\&feature=youtu.be\&a

(26.) 'My Ability' can be heard at ReverbNation: http://www.reverbnation.com/mpofunambaone

(27.) See the British Paraorchestra, 'Get

Involved’: http://www.paraorchestra.com/editorial.php?ref=get-involved 